\title{
Encontros cartografados: reflexões sobre encontros entre meninos e educadores de rua
}

\author{
Julia Frajtag Sauma
}

\begin{abstract}
resumo Este trabalho tem como objetivo principal conectar uma pesquisa de campo, sobre os encontros entre meninos e educadores de rua, com perspectivas teórico-metodológicas que visam re-situar a representação etnográfica. Para esse fim, ofereço um contraste entre recentes análises antropológicas sobre este tema, em que uma interpretação é elaborada a partir de termos como família e identidade, e uma análise que parte das relaçóes sociais que ultrapassam esses conceitos. Desta forma, proponho tornar um pouco mais visíveis alguns dos múltiplos planos sociais que atravessam esse campo de pesquisa e de relaçôes. Este artigo busca elaborar uma alternativa para a análise de fenômenos que são normalmente definidos por sua "carência" e esboça, assim, uma reflexão sobre a própria idéia de uma "realidade" etnográfica.
\end{abstract}

palavras-chaves Meninos de rua. ONGs. Antropologia urbana. Etnografia. Verdade.

\section{Introdução}

Os chamados "meninos de rua” sem dúvida constituem um desses temas sobre os quais é, ao mesmo tempo, muito fácil e muito difícil falar. ${ }^{1}$ No Brasil, desde o famoso romance utó-

1. Existe uma ampla discussão sobre como denominar este "grupo", sendo que, atualmente, os movimentos sociais que trabalham com as pessoas que dele fazem parte preferem chamá-las de "crianças em situação de rua”, algo que em si mereceria uma análise. Neste trabalho, a falta de tempo e espaço não permitem tal elaboração, mas vale mencionar que um dos grandes problemas dessa expressão recai sobre a distinção entre crianças que moram habitualmente nas ruas e crianças que simplesmente trabalham nas ruas, uma pico de Jorge Amado, Capitães de Areia - que destacava a rebeldia e a beleza das relaçóes estabelecidas nas ruas de Salvador -, até a década de 1980, com a atuação de ONGs com menores de rua nas diversas metrópoles do Brasil, a existência desse grupo de fantasmas sociais nunca deixou de nos lembrar as violências inerentes à nossa atual forma de socialidade. Até meados da década de 1990, a atuação de ONGs nessa área era considerada inovadora, fundada pela transformação e pela resistência. Porém, desde então esses primeiros impulsos, constitucionais e sociais, perderam sua força e, hoje em dia, em situaçóes de violência urbana cada vez mais assustadoras, os nossos fantasmas urbanos que serviram e servem como objeto de tanto barulho continuam a perambular, roubar, viver e morrer nas "pistas" das grandes cidades brasileiras $^{3}$.

questão que se manifestou durante os esforços para a quantificação do "problema” (Cf. Rizzini 1992; Hecht 1998). Já que este trabalho pretende se prender às experiências e opinióes dos atores dentro do campo mais do que às dos acadêmicos envolvidos nessa discussão, e visto que tanto os meninos como os educadores utilizam a expressão "meninos de rua", escolhi manter essa categoria táo polêmica.

2. Os meninos e meninas de rua costumam chamar a rua de "pista". Todas as palavras que estiverem entre aspas ao longo do texto vêm diretamente dos atores que moram ou trabalham no abrigo, podendo ser, assim, denominadas como categorias nativas - tanto dos meninos de rua quanto dos educadores. Os conceitos em itálico vêm dos autores que influenciaram este trabalho de diversas formas.

3. Para uma história mais detalhada do desenvolvimento desses movimentos e organizaçóes sociais, cf. Gregori (2000). 
Este trabalho apresenta uma reflexáo inicial sobre alguns dos múltiplos elementos que se destacam em um grupo de meninos e educadores de rua que se encontram diariamente em uma praça da cidade do Rio de Janeiro, a partir de dados coletados durante dez meses de trabalho de campo desenvolvido entre eles. A maioria dos trabalhos desenvolvidos sobre esse tema tende a apresentar dados sobre diversos grupos de meninos e educadores. $\mathrm{O}$ foco deste trabalho sobre um grupo específico - e, mais significantemente, sobre os encontros desse grupo - visa estabelecer, além de uma visão mais complexa sobre as relaçóes entre os atores, uma proposta metodológica potencialmente interessante para estudos urbanos, que pretende ser fiel às mais tradicionais metas antropológicas. $\mathrm{O}$ maior objetivo dessa proposta é multiplicar o potencial de descrição sobre a conexão entre diversos mundos, diversos planos aparentemente distantes.

\section{Princípios teórico-metodológicos}

Como fazer antropologia na cidade, nas chamadas sociedades complexas, sem a necessidade de utilizar tais expressóes e as aspas que as acompanham? Será possível continuar com os tradicionais padróes metodológicos e teóricos, ou será que precisamos de uma revolução metodológica? Essas parecem ser algumas das grandes perguntas da disciplina. Acredito que a tradicional noção de crise na disciplina ${ }^{4}$, usualmente ligada a essas questóes, tem o efeito de limitar as experiências concretas de antropólo-

4. Como destacado por Goldman (1994), este é um tema que percorre toda a história da antropologia, desde Frazer, com o desaparecimento do objeto antropológico, até hoje, com o "seqüestro" do estudo antropológico pelo pensamento pós-moderno. O esforço aqui é de tentar incorporar estes movimentos e não simplesmente ignorá-los ou aceitá-los sem restriçôes. gos contemporâneos, dentro e fora do campo. Penso que essa reduçáo, essa aparente crise e a suposta necessidade de revolução resultaram em fragmentaçóes antropológicas que, para utilizar os termos de Deleuze e Guattari, muitas vezes reterritorializam-se duramente. Uma dessas fragmentaçôes é a divisão entre a antropologia teórica e a antropologia aplicada: o buraco negro e o muro branco do meu campo, uma das rostificaçóes da antropologia. ${ }^{5}$

Há muito tempo - desde que iniciei meu trabalho de campo com meninos de rua, por volta de 2000 -, pergunto-me como atravessar

5. No sétimo platô - Année Zero: Visageité - Deleuze e Guattari exploram a identificação de duas semióticas: a da significância e a da subjetividade, o muro branco e o buraco negro. Porém, eles também exprimem a clara interdependência entre esses planos e, portanto, colocam a necessidade de se pensar esse funcionamento como um rosto, um sistema muro branco-buraco negro. Esse é um sistema de índice que territorializa, que dá forma ao significado a partir da subjetividade e que, por função, orienta o significado: "Os rostos não são primeiramente individuais, eles definem zonas de freqüência e probabilidade, delimitam um campo que neutraliza de saída as expressóes e conexóes rebeldes às significaçôes conformadas" (1980: 206 - tradução da autora). O sistema rosto combinado com o sistema paisagem formam os dois dispositivos de desterritorialização, horizontal e vertical, que forçam a reterritorialização de um sobre o outro, sobre a complementaridade ou sobre a sobrecodificação. Guattari sugere que essa máquina abstrata de rostificação entra em jogo em qualquer relação que envolve uma economia ou organização do poder - do desejo - e que essa engrenagem delimita o significado, neutralizando a "aspereza da alteridade" e reduzindo a vitalidade humana a uma série de dicotomias ( $I b i-$ dem: 214-215) Aqui, a fragmentação da antropologia $\mathrm{em}$, entre muitas outras, uma antropologia aplicada e uma antropologia teórica, neutraliza as diversas multiplicidades que podem, e devem, aparecer na representação antropológica. Assim, um rosto delimitado em que tipos de antropologia podem aparecer nega a possibilidade de uma antropologia que possibilite a suscitação de vários planos de imanência e a comunicação entre eles. 
esta divisão: a lacuna entre aqueles que analisam a experiência de crianças e adolescentes de rua quase como uma realidade cultural e aqueles que interpretam a mesma experiência como um problema social para o qual a pesquisa antropológica pode fornecer soluçóes. Minha experiência com meninos e adolescentes que vivem ou transitam pelas ruas do Rio de Janeiro indica, é claro, que nada é tấo simples e, mais do que isso, que essas visóes reduzem a experiência concreta dessas crianças e adolescentes a fórmulas unidimensionais: nem a versão teórica, nem a versão aplicada permitem-nos pensar a complexidade das forças que estão em jogo e, em vez de dar vida à experiência, esta é sufocada brutalmente.

Uma clara indicação dessa limitação aparece em trabalhos sobre meninos de rua que não conseguem se concentrar em um só grupo (dois exemplos recentes são Gregori 2000; Hecht 1998). A explicação para isso seria a necessidade de tentar quantificar a situação, uma prática sociologizante acompanhada por uma identificaçáo imediata do objeto de pesquisa como um problema social, e, além disso, por uma negação da complexidade e dos múltiplos planos que existem nesse campo de pesquisa - como se, por ser um tema familiar, os pesquisadores não soubessem muito bem como conduzir uma análise verdadeiramente antropológica, isto é, uma análise que se detém na multiplicidade da socialidade dos atores em questáo e que não se limita à visão dominante dos mesmos. Porém, sendo trabalhos antropológicos com base em pesquisas de campo, os autores também colocam a necessidade de demonstrar a heterogeneidade dos meninos e meninas de rua, suas práticas sociais, suas origens diferentes, sua cultura.

A primeira implicação importante dessa descrição é a de desmistificarmos a noção corrente de que existe um comportamento genérico dos meninos de rua. Comparando esses agrupamentos, foi possível reconhecer que há uma significativa variação em seus modos de se relacionar. $E$, o que me parece mais intrigante: essa variação está diretamente ligada ao estabelecimento de contatos e de convívio com um contexto de interação específico (Gregori 2000: 123).

A meu ver, a simples constatação dos autores a respeito da convergência dos dois lados da moeda não resolve o problema. Essa solução descreve a heterogeneidade dos atores muito superficialmente a partir da diferenciação entre grupos e entre indivíduos, mas a heterogênese ${ }^{6}$ implícita dentro dos grupos e dos indivíduos, em suas falas e em suas açóes concretas, não é analisada. Duas saídas se apresentam para esses autores: no caso de um dado concreto a ser analisado, a interpretação se baseia em semióticas significantes $^{7}$ - normalmente ligada à família e à identidade -, no caso da constatação generalizada de uma falta de coerência nas falas dos meninos e meninas (e mesmo entre educa-

6. Em Caosmose: Um novo paradigma estético, Félix Guattari desenvolve a noção de heterogênese: uma categoria relacionada à de causa eficiente, correspondente à constituição de universos de referência. Como colocado pelo autor, a heterogênese é "uma dimensão de produção ontológica que implica que se abandone a idéia de que existiria um Ser subsumido às diferentes categorias heterogêneas de entes (...) Não existe uma substância ontológica única se perfilando com suas significações 'sempre já presentes' (...) Para além da criação semiológica de sentido, se coloca a questão da criação de textura ontológica heterogênea” (1992: 88-89). A heterogênese implica uma dinâmica de constante diferenciação, seguida por uma necessária singularização em novos territórios existenciais, que define os processos de desterritorialização e reterritorialização criativas.

7. Aqui as semióticas significantes 'que articulam cadeias significantes e conteúdos significados' se distinguem das semióticas a-significantes "que agem a partir de cadeias sintagmáticas, sem engendramento de efeitos de significação no sentido lingüístico" (Guattari e Rolnik 1986: 317). 
dores), os autores se limitam a observar que o pesquisador tem que aprender a distinguir as mentiras e as fantasias da verdade.

Acredito que desenvolvi a habilidade de distinguir precisamente quando as crianças estavam recontando fantasias, quando elas estavam falando o que elas achavam que seu interlocutor queria ouvir e quando estavam dizendo o que se poderia chamar de verdade. Mas, como qualquer etnógrafo, eu nunca tive certeza (...) Outras vezes, era impossível desembaralhar os fatos de uma teia de fantasias (Hecht 1998: 12; tradução da autora).

Esta resposta a problemas de campo muito comuns não me parece satisfatória se aceitarmos que o ofício principal do antropólogo é a descrição etnográfica, ou seja, a descrição e a apresentação amplas e detalhadas de qualquer objeto de pesquisa ${ }^{8}$. Quanto ao "problema" apresentado por Hecht - a saber, o das aparentes contradiçóes nas falas e açóes dos atores envolvidos -, acho improvável que um bom pesquisador de grupos indígenas possa perseguir tal questão com o propósito de distinguir o que é verdade e o que é fantasia nas narrativas de seus informantes. Dessa forma, a suposta familiaridade com o mundo dos meninos de rua prejudica o trabalho do pesquisador - são crianças, pobres e sobreviventes - e esse é um problema grave em muitos trabalhos de antropologia urbana. Minha preocupação deve-se à

8. Vale notar que o uso dos dois termos descrição e representação segue uma lógica específica sobre a descrição etnográfica, no sentido em que uma descrição pura de um objeto é impossível e, portanto, sempre representacional: "O estudo ou representação de outra cultura não é uma mera 'descrição' do mesmo jeito em que uma pintura não 'descreve' aquilo que está sendo descrito. Nos dois casos ocorre uma simbolização, que está conectada à intenção do antropólogo ou do artista de representar o objeto no primeiro lugar" (Wagner [1975] 1981:11 - tradução da autora). recorrência das descriçóes de contradição nas falas e açóes dos meninos e meninas de rua, segundo os trabalhos de diversos autores, e pode ser traduzida na seguinte pergunta: já que estas contradiçôes são tão normais e fazem parte do cotidiano, será que elas não estabelecem um dado significativo para análise? Parece-me que a mentira e a fantasia são dados muito interessantes para serem analisados e acredito que temos que ter mais cuidado com a idéia de estarmos fazendo antropologia em casa:

Se os antropólogos, enquanto antropólogos, estâo ou não em casa não deve ser decidido pelo fato de se chamarem de Malaios, de pertencerem aos Viajantes ou de terem nascido em Essex, mas pela relação entre suas técnicas de organização de conhecimento e o modo pelo qual as pessoas organizam o conhecimento sobre si-mesmas (Strathern 1987: 31; tradução da autora).

A questão da interpretação de dados concretos é um problema um pouco mais polêmico e complicado e, por falta de espaço e de tempo, não pretendo desenvolver uma elaboração muito detalhada desse debate. Porém, acredito que uma demonstraçáo do problema, a partir de questóes específicas do campo, pode tornar visíveis as dificuldades em questão.

A família é um dos grandes significantes da antropologia social e, junto com o parentesco, forma uma base importante para a interpretação antropológica. É claro que em pesquisas sobre crianças e adolescentes esse dispositivo é especialmente forte. Porém, este último não deve sufocar outros planos, quer dizer, outras relações significativas e seus vínculos não somente com a falta de uma família tradicional, mas também com seu ambiente mais imediato: a rua. Para isso, o uso dos conceitos de família ou de parentesco, assim como de outros significantes, em uma análise antropológica, precisa ser repensado. 
Por exemplo, quando consideramos a relação entre meninos de rua, ou entre educadores de rua e os meninos e meninas de rua, a questão da família não pode se limitar à idéia de uma substituição; esses movimentos são muito mais complexos, muito mais ricos, e merecem uma maior atenção. Um dado que pode ilustrar essa observação são as usuais interpretaçóes da existência de "mães-de-rua" entre meninos e meninas de rua. Esse fenômeno tende a ser pensado a partir da idéia de uma simulação ou mimetização do papel familiar de máe para legitimar uma liderança entre as meninas de rua. Nesse sentido e diferentemente dos meninos, as meninas precisariam lançar mão de um código da sociedade para estabelecerem sua autoridade. Esta interpretação não se adéqua bem a meus dados de campo: em primeiro lugar porque encontrei tanto "pais-de-rua" quanto "mães-derua” e, portanto, esse fenômeno não se limita a uma questão de gênero. Além disso, ela me parece incompleta na medida em que analisa a parte família e sociedade do dispositivo "mãede-rua", mas deixa de analisar amplamente um outro lado desse fenômeno: sua parte "de-rua", que é igualmente importante para a produção da subjetividade desses atores.

Por exemplo, para Gregori (2000), as relações ativadas por meninos na rua são relações de sobrevivência, de viraçâo em circunstâncias difíceis e, certamente, ela tem razão. Porém,

9. Segundo as idéias de Guattari, essas noçôes seriam algumas das máquinas sociais da representação antropológica. "A mecânica é relativamente fechada sobre si mesma: ela só mantém com o exterior relações perfeitamente codificadas. As máquinas consideradas em suas evoluçóes históricas, constituem, ao contrário, um phylum comparável aos das espécies vivas. Elas engendram-se umas às outras, selecionam-se, eliminam-se, fazendo aparecer novas linhas de potencialidades... As máquinas (técnicas, teóricas, sociais, estéticas) nunca funcionam isoladamente, mas por agregação ou por agenciamento" (Guattari e Rolnik 1986: 320). como também é descrito pela autora, para a maioria desses meninos e meninas, essa viraçâo é o funcionamento prático de uma vida toda. Entáo, por que a experiência de vida deles pode ser descrita como uma simulação, como algo artificial, sem um valor independente? Acredito que esse é um problema inerente à tentativa de elaborar uma interpretação da alteridade de relaçóes entre pessoas, como meninos e meninas de rua. Esse dispositivo analítico não permite uma descrição ampla dessas relaçóes e tende a jogá-las contra o muro branco, as semióticas significantes, que formam as relaçóes sociais com as quais ficamos mais tranqüilos, nesse caso, a família. Assim, noções como simulaçâo e substituição são utilizadas para demarcar esta falta de valor, própria às relaçôes em questão.

Gregori interpreta a posição "mãe-de-rua" da seguinte maneira: a menina constrói sua posição através de regras com conteúdos convencionais (como o de náo poder usar drogas, por exemplo). Ela exerce o papel de punir os seus "filhos" nos casos freqüentes de desobediência. Segundo a análise da autora, o conteúdo da regra importa, mas não exprime uma crença efetiva, já que as próprias "mães-de-rua" não seguem suas regras. Para garantir a eficiência da substituição, diz Gregori, precisa-se estabelecer a autoridade e a legitimidade do papel a partir da punição e que, portanto, esta prática ilustra a fixação de referências em um universo social cujos códigos não são reconhecidos publicamente.

Além de congelar relaçóes familiares em um padráo normativo, vemos que a autora se fixa na relação dos meninos com a sociedade, mas ela não descreve esse fenômeno a partir da relação entre esses indivíduos publicamente desconhecidos e, assim, ela não reconhece a importância dessas relações. As descriçóes antropológicas das relações de rua dessas crianças e adolescentes tendem a destacar sua qualidade temporária, normalmente baseada nas falas dos seus informantes tiradas de entrevistas gravadas. Meninos e meninas de 
rua, quando entrevistados formalmente, não falam tanto de suas relaçóes com outros "de-rua" 10 como da importância de ser independente e de "se virar". Contudo, durante os dez meses do meu trabalho de campo, constatei que, muitas vezes, essas falas não encontravam total concordância com as açóes concretas dos meninos e meninas. Além disso, quando conversavam - fora de uma situação de entrevistas - o assunto ao qual eles mais se referiam dizia respeito às suas relaçóes com seus amigos "de-rua”. Vêem-se logo os problemas de uma pesquisa que não se detém em um só grupo e que, por isso, se baseia sobretudo em entrevistas.

Os meninos e meninas com quem encontro falam constantemente da importância de suas mães: "mãe só tem uma, tia". Quando são perguntados sobre a sua "mãe-de-rua", indicam a diferença entre a mãe biológica e a de rua. Em certos momentos eles glorificam a mãe biológica, mas, em muitos outros, eles a criticam e guardam presentes para levar às suas "mães-de-rua”. Como esses movimentos coexistem? Qual seria o mais legítimo? Seriam essas descrições contradições de viradores profissionais? São questôes difíceis, mas, como explicitado por Wagner (1974), não acredito que o papel do pesquisador se defina por uma determinação da realidade, portanto, a pergunta mais eficiente seria a primeira: Como esses dois planos funcionam ao mesmo tempo? O que temos são dois movimentos e acredito que esses se preenchem e se elucidam através das noçóes de molaridade e de molecularidade desenvolvidas por Deleuze e Guattari ${ }^{11}$.

10. Expressão utilizada por meninos e meninas de rua e por educadores, que marca uma distinção com os meninos de casa e os infratores. Esta expressão de pertencimento enfatiza a necessidade de nos determos mais sobre as relações desenvolvidas na rua e de sofisticar nossas descriçóes sobre as relaçóes destes atores com a "sociedade".

11. Como dizem Deleuze e Guattari, "O homem é um animal segmentar" e a vida é segmentarizada, tanto espacialmente quanto socialmente. Os segmentos so-
Segundo a proposta destes autores, esses movimentos são simultâneos: um depende do outro para sobreviver, para existir. Portanto, voltando ao exemplo, no movimento molar, um movimento de encontro e visibilidade, temos a glorificação da mãe tanto nas falas dos meninos e meninas quanto em sua conexáo para a criação da figura "mãe-de-rua": uma evidência do uso de semióticas significantes. Ao mesmo tempo, temos um movimento molecular - um movimento de agenciamento e invisibilidade (pública) - nas ações afetivas deles com suas "mães-de-rua” e a rejeição da mãe biológica, da casa e de tudo que é representativo disso. Nesse último movimento, a idéia de simulação não é suficiente, pois, como eles mesmos colocam, não se trata de uma substituição - eles só têm uma mãe -, mas da criação de um novo plano de relação. Desse modo, a heterogênese das relações vem a funcionar na criação de uma linha de fuga de um território já existente - o de máe em todos os seus sentidos molares - para a produção de um novo território existencial - o

ciais, em qualquer situação, seguem flexivelmente os movimentos de fusão e fissão - e a comunicação entre estes segmentos se faz neste movimento -, sendo esta segmentaridade binária, circular ou linear. Para identificarmos algumas das patologias do nosso pensamento, começamos por identificar os tipos de segmentação que nos acometem. Em "Micropolitique et Segmentarité”, o nono dos Mille Plateaux (1980), Deleuze e Guattari começam por binarizar e nos oferecem dois "tipos" de segmentaridade: uma primitiva e uma moderna, uma flexível e uma dura, uma molecular e uma molar. Esta dicotomia serve como salto para sua reflexão, que também começa oferecendo dois processos, dois movimentos diferentes da segmentaridade: a árvore e o rizoma. Acredito que esta conexão serve para chegarmos ao cerne do assunto, a árvore não sobrevive sem o rizoma e vice-versa, portanto toda sociedade, bem como todo indivíduo, é atravessada por dois tipos de segmentaridade, uma molar e uma molecular. Não se pensa em uma dicotomia, mas em uma política que é, ao mesmo tempo, macro e micro, homem e mulher e suas múltiplas combinaçóes. 
de "mãe-de-rua" - por uma reterritorialização flexível na conexão entre relações heterogêneas onde encontramos o funcionamento de semióticas a-significantes.

Enquanto a "mãe-de-rua" ou o "pai-de-rua" têm o papel de proteger e punir, eles também são punidos e protegidos por seus "filhosde-rua”. Assim, o conflito e a facilidade com que os meninos e meninas rompem com suas "mães-de-rua" não representa simplesmente a conseqüência de uma substituição ou simulação temporária, mas sim um elemento definitivo das relaçôes entres esses atores. Brigar com sua "mãe-de-rua” ou seu "pai-de-rua” não quer dizer somente quebrar com uma autoridade, pois essa posição é definida tanto pela ação e pela relação entre os meninos e meninas, quanto pela relação entre esse papel e a "real" posição de mãe ou de pai. Se a "mãe-de-rua" faz algo de errado nos olhos de seus "filhos-de-rua", sua posição muda instantaneamente, algo que náo acontece com a mãe ou pai biológico. Além disso, romper com uma "mãe-de-rua" ou o "pai-de-rua” não significa deixar de conviver com ele ou ela, deixar de se relacionar, como é o caso entre muitos meninos e meninas de rua e seus pais biológicos enquanto os meninos estão na rua. Embora os meninos e meninas falem da maior importância da mãe biológica, suas ações concretas demonstram igual importância dada às suas relaçóes com as crianças, os adolescentes e os adultos com quem eles convivem na rua. Dessa forma, a noção de uma simulação me parece fraca, pois esta interpretação subordina as relaçóes de rua às relaçóes de família e, neste sentido, limita a criatividade dessas relaçóes moleculares, que são definidas por sua flexibilidade.

A importância dada às relaçóes de família - não somente por antropólogos, mas também dentro do que Guattari chama de CMI (Capitalismo Mundial Integrado) e, especificamente, nesse campo de relaçóes entre população de rua e ONGs - fornece um meio de controlar o encontro com a molecularidade dos meninos de rua, mas também fornece a visibilidade $\mathrm{da}$ forma heterogenética em que essas relações se articulam com outras relaçóes para o desenvolvimento subjetivo dos atores envolvidos. Essa visibilidade se coloca a partir do encontro das diversas relaçóes sociais em jogo nesse meio: a família é somente uma delas, mas é uma $m a ́$ quina social especialmente pesada ${ }^{12}$. Esclareço, segundo o trabalho de Guattari, a subjetividade dos atores no campo é produzida e individuada por agenciamentos coletivos de enunciação; a subjetividade é:

O conjunto das condiçóes que torna possível que instâncias individuais e/ou coletivas estejam em posição de emergir como território existencial auto-referencial, em adjacência ou em relação de delimitaçấo com uma alteridade ela mesma subjetiva.

Assim, em certos contextos sociais e semiológicos, a subjetividade se individua: uma pessoa tida como responsável por si mesma, se posiciona em meio a relaçóes de alteridade regidas por usos familiares (...) Em outras condiçôes, a subjetividade se faz coletiva (...) o termo "coletivo" deve ser entendido aqui no sentido de uma multiplicidade que se desenvolve para além do indivíduo, junto ao socius, assim como aquém de pessoa, junto a intensidades pré-verbais, derivando de uma lógica dos afetos mais do que uma lógica de conjuntos bem circunscritos (Guattari [1992] 2000: 19-20).

Guattari sugere que a parte náo-humana e pré-pessoal da subjetividade é essencial para o desenvolvimento da heterogênese, na medida em que as máquinas de subjetivação - da produção

12. Algumas das outras máquinas sociais que funcionam amplamente nesse meio podem ser vistas no uso das seguintes noçôes: “educação”, "delinqüência”, “inclusão social”, "solidariedade". 
da subjetividade - não trabalham apenas nas relaçóes interpessoais como também se colocam a partir de máquinas sociais - mass-mediáticas e lingüísticas. Segundo o autor, cada grupo social "veicula seu próprio sistema de modelização da subjetividade a partir do qual ele se posiciona em relaçáo aos seus afetos, suas angústias e tenta gerir suas inibiçóes e suas pulsóes" (Ibidem: 2122). Nesse caso, o que acontece quando reunimos sistemas de modelização da subjetividade heterogêneos em um encontro intenso e multiterritorial?

O projeto de abordagem de rua que é o foco dessa pesquisa faz essencialmente isso, não somente no sentido do encontro antropológico com os meninos de rua, mas, mais do que isso, no encontro molar entre meninos de rua, entre os meninos e os educadores, e entre cada um desses dois grupos com a assistente social, com as ONGs, com o governo, com o sistema capitalista. Não é suficiente identificar os meninos como os pobres, os que sobrevivem, os que se viram, e deixar de elaborar o funcionamento detalhado - nos micro-planos e nos macro-planos desse dado - como se fosse algo puramente explicativo de uma situação de origem e como se não afetasse profundamente o cotidiano dos atores de diversas formas.

Minha perspectiva se ajusta à tentativa de atravessar os dispositivos usuais da descrição para alcançar uma forma de explicitar a complexidade desses atores, em vez de reduzi-la às interpretoses e significâncias ${ }^{13}$. Busco, portanto,

13. No quinto platô "Sobre múltiplos regimes de signos", Deleuze e Guattari desenvolvem uma análise de quatro sistemas semióticos: o sistema presignificante, o significante, o contrasignificante e um possignificante. Eles identificam o sistema significante, que funciona a partir de significâncias e interpretoses infinitas, como "a neurose fundamental da humanidade". Um sistema semiótico despótico cujo funcionamento não permite linhas de fuga positivas, somente negativas, e que se baseia na identificação absoluta do excluído - o "contra-corpo", aquele que ultrapassa o nível de passar para o funcionamento concreto das diversas relaçóes sociais envolvidas no encontro pesquisado, isto é, alcançar as micropolíticas em jogo nesse contexto. Assim, proponho oferecer uma breve cartografia de minha pesquisa de campo, que tem como objetivo a produção de um mapeamento de seus encontros e agenciamentos $^{14}$ sociais.

\section{Verdade e mentira - um campo cartografado}

Como dissemos acima, molar e molecular são planos de referência interdependentes, ainda que distintos ${ }^{15}$. Náo se trata, de forma alguma, de opô-los como o mal ao bem, uma

desterritorialização do signo significante no centro do sistema (1980: 144-47). Nas análises tradicionais do contexto em questão, a família muitas vezes funciona como este centro e as interpretaçóes que dele se seguem prendem as relações analisadas a este signo.

14. Segundo Guattari, "um agenciamento comporta componentes heterogêneos, tanto de ordem biológica, quanto social, maquínica, gnosiológica, imaginária” (Guattari \& Rolnik 1986: 317).

15. Os planos de referência molar (arborescente, organizador, significante, mecânico, linear) e molecular (rizomático, conectativo, a-significante, maquínico, superlinear), que Deleuze e Guattari utilizam na descrição de movimentos e formas relacionais, carregam uma qualidade fractal que não permite uma oposição dualista. $\mathrm{Na}$ descrição das multiplicidades que formam o inconsciente, Deleuze e Guattari, distinguem entre multiplicidades molares (extensivas, divisíveis, unificáveis, totalizáveis, organizáveis, conscientes ou pré-conscientes) e multiplicidades moleculares (libidinais, inconscientes e intensivas que não se dividem sem mudarem de natureza). Porém, eles advertem contra o estabelecimento de uma oposição dualista entre o molar e o molecular, que não seria nada melhor do que o dualismo entre o um e o múltiplo da psicanálise, que eles buscam ultrapassar: "Existem somente multiplicidades de multiplicidades formando um único agenciamento: bandos em massa e massas em bando. Árvores têm linhas rizomáticas e o rizoma pontos de arborescência”. (1980: 47 - tradução da autora). 
vez que constituem eixos necessários, ainda que os extremos de cada um deles tenham suas potencialidades perigosas: no molar - o muro branco, a falta de criatividade, a redundância; no molecular - o buraco negro, a loucura, a morte. Toda experiência precisa se reterritorializar, se molarizar, para criar e, ao mesmo tempo, todo território precisa se desterritorializar, produzir linhas de fuga, se molecularizar, para criar. Apesar das novas relaçóes criadas, as experiências de rua dos meninos e meninas que acompanhei durante os últimos dez meses são muitas vezes violentas e tristes. Se tomamos como regra absoluta do etnógrafo que a representação da experiência dos nativos deve ser a base de qualquer pesquisa, tanto a idéia de que os meninos oferecem uma nova e melhor maneira de viver, quanto a noção de que a identidade e a familia (ou melhor a falta dela) rege a vida deles, não têm coerência nenhuma. Como já indiquei no início do trabalho, a intenção é ultrapassar tanto descrições meramente culturalistas quanto aquelas que se fixam na pura negatividade da situação, quer dizer, que tratam meninos de rua como nada mais do que problemas sociais a serem resolvidos. Por conseguinte, tanto o molar quanto o molecular merecem suas elaboraçóes.

Como já foi explicitado, a questão da verdade se coloca de forma instigante neste trabalho. Se apreendemos a noção de verdade usual como inerentemente molar, os atores do campo em questão se colocam da seguinte forma: os meninos são os sem-verdade; os educadores, por via de seus cargos, sáo os emissores da verdade; a assistente social, assim como a ONG e seus coordenadores sáo os produtores e os donos da verdade. A verdade é um bem importantíssimo para os seus produtores e donos porque ela define a existência e a coerência dos mesmos. Para os emissores, a verdade é um apoio fundamental em seu enfrentamento da molecularidade e os sem-verdade também utilizam a verdade como apoio em seu encontro com a molaridade apresentada no trabalho de "educação". A forma com que essa verdade permeia esse campo requer muita atenção, pois essa influência é central na atuação de projetos, governamentais ou não-governamentais, junto aos meninos e meninas de rua. Sem essa força, moldadora e delimitadora, a legitimidade desses atores seria impossível e, mais do que isso, o funcionamento do encontro entre os meninos e os educadores seria impensável. Se a verdade não é oferecida aos perdidos, aos que se desviaram do caminho comum, como encontrá-los? Essa verdade é uma potência rostificadora da experiência social ${ }^{16}$.

Nessa linha, uma discussão mais ampla sobre a constituição dessa verdade molar, a partir de uma análise da noção de moralidade - tema que permeia todas as tentativas de "resgate"17 de meninos de rua - é necessária, porém, por enquanto, deixo tal discussão para autores mais aptos (ver Nietzsche [1887] 1998; Donzelot [1977] 1980). Antes de mais nada, também precisamos reconhecer uma outra verdade,

\section{Ver nota 5.}

17. Resgatar os meninos e meninas da rua é a concepção oficial do trabalho de abordagem de rua. Tanto a coordenação quanto os educadores usam essa noção, que faz parte de todo um vocabulário descritivo da situação desses meninos como um problema social, assim como a descrição deles como "crianças em situação de rua", "crianças em risco social", "crianças socialmente excluídas" e toda uma outra série de expressóes que determinam, ou rostificam, a marginalidade dessas crianças e adolescentes e enfatiza a necessidade de reinserção total dentro das normas sociais e de socialidade capitalística: "A marginalidade chama o recentramento, a recuperação" (Guattari [1977] 1987: 46). No lugar de marginalidade, Guattari propõe a noção de "minoritário", que, em vez de considerar fenômenos sociais, como o dos meninos de rua, como uma carência, foca-se na maneira em que estas minorias sociais "exploram os problemas da economia do desejo (do sistema capitalístico) no campo urbano" (Ibidem: 47). 
mais molecular, maquínica ${ }^{18}$ e a-significante: a verdade como redefinidora de conceitos. Para facilitar, utilizaremos o exemplo anterior para tentar elucidar essa colocação e o problema antropológico em questão. Os termos mãe e rua - em seus aspectos molares, como semióticas significantes da família (o privado) e do espaço público - são utilizados criativamente pelos meninos e meninas de rua no termo "mãe-de-rua" para criar uma nova relação, uma nova socialidade. Se pensamos no termo como resultado das relaçóes e não o oposto ${ }^{19}$, no momento em que esse novo termo é estabelecido, por novas relaçôes, ele também automaticamente redefine os anteriores para os atores em questão, já que as relaçóes de rua mudam as relaçóes de casa e vice-versa. Para usar uma noção wagneriana, no ato de se relacionar, distinções são feitas e estas fazem aparecer novas categorias. Com isso, parece-me necessário procurar a relação ou as relações por trás das distinções que criam os termos, em vez de os identificar de saída e, assim, molarizar um sentido definidor de cada termo (Wagner 1974; Strathern 1988).

$\mathrm{O}$ que isso tem a ver com a verdade? Tudo, já que a representação de qualquer fenômeno social é necessariamente difícil, como vimos no trabalho de Gregori, quando a verdade é definida pela alteridade. No caso citado, a dificuldade começa quando a noção de "mãe-de-rua" é tomada como uma identidade e náo como o resultado de uma relação. Esse ato automaticamente define a "mãe-de-rua" como diferente da mãe e essa alteridade se consolida a partir da noçáo de simulação. Nessa perspectiva, a relação mãe é absoluta, é um fato concreto que não

18. Para Guattari, a máquina social funciona a partir de um agenciamento maquínico com diversas outras máquinas sociais, aqui, a verdade, enquanto máquina social, é agenciada maquinicamente no ato de invenção do termo "mãe-de-rua", com a máquina público-privado, que é exposto pelos termos iniciais mãe e rua.

19. Ver Strathern (1988). pode ser alterado ou transferido a uma relação tão temporária, tão insegura quanto "mãe-derua”. Em Defining Anthropological Truth, Holbraad (2004) explicita a relação íntima entre a alteridade e a verdade, já que a primeira é necessariamente definida pela negação da segunda:

Supostamente, se nosso objetivo é a explicação causal ou a interpretação adequada, estamos basicamente no negócio de "representar" os conceitos e práticas dos outros, que não são somente interessantes mas também disponíveis (compreensíveis) como negaçóes dos nossos conceitos e práticas (Holbraad 2004; tradução da autora).

$\mathrm{O}$ autor defende a necessidade de ir além do conceito comum de verdade, que inerentemente se opóe à falsidade, para alcançarmos o objetivo definidor da antropologia, a saber, a representação dos fenômenos que observamos e dos quais participamos no trabalho de campo. O que precisamos, segundo o autor, é um conceito diferente de verdade. Para esse fim, e com base na idéia de que a criação de novos sentidos é um aspecto irredutível da vida social, Holbraad propóe a noção de definição inventiva que também distingue a noção de definição da noção tradicional de verdade. $\mathrm{O}$ autor define esse ato-conceito como "um ato-fala que inaugura um novo sentido através da combinação de dois ou mais sentidos anteriormente desconexos":

Colocado como uma condição para sua própria definição, o definível toma precedência sobre seus definidores e, assim, náo se pode dizer que esses últimos inauguram o anterior. Então, uma vez que definiçôes inventivas são definidas como inauguraçôes - quer dizer, como invenções de (novos) sentidos -, segue que, diferentemente das definições verdade-funcionais, definições inventivas não são reivindicaçooes-da-verdade (Ibidem; tradução da autora). 
Holbraad desenvolve essa análise a partir de sua pesquisa sobre o culto do Ifá, em Cuba, para melhor descrever a maneira que os babalaôs utilizam a noção de verdade em suas afirmaçóes sobre o caráter infalsificável dos pronunciamentos dos oráculos. Mas acredito que podemos utilizar a noção de definição inventiva quando consideramos novas maneiras de utilização de termos ou conceitos comuns. Esse seria o caso do termo "mãe-de-rua”, pois, no ato da utilizaçáo desse termo por meninos e meninas de rua, tanto máe quanto rua são colocados a partir de novos sentidos, novas experiências, novas relaçóes. Assim, nesse plano descritivo, a proposta de interpretaçáo - tanto pela confinação dessa categoria às meninas de rua, quanto pela adoção da noção de simulação e, portanto, pela insistência na noção de identidade - perde sua eficácia descritiva e representativa.

Vale enfatizar mais uma vez que Holbraad coloca, além de um novo parâmetro teórico, uma outra proposta metodológica, segundo a qual os pesquisadores devem voltar sua atenção para experiências mais fluidas e complexas, mais moleculares, do que aquelas por trás de noções molares, como a de identidade. $\mathrm{O}$ que não quer dizer, é claro, que noçôes molares como a de identidade não tenham seu lugar no trabalho antropológico, especialmente ao se considerar a maneira como tais conceitos são utilizados muitas vezes por nossos informantes, criando, assim, o campo em questão. Todavia, parece que essas noçóes têm ocupado, há muito tempo, um lugar hegemônico em pesquisas antropológicas, e que um equilíbrio precisa ser estabelecido. Além disso, tal esforço também envolveria uma reavaliação da maneira segundo a qual temos analisado noçóes molares. Quero dizer com isso que ao considerar-se a existência de relações moleculares as relaçóes molares são necessariamente redefinidas e, por isso, precisam ser redescritas.
Para melhor pensarmos o uso metodológico da proposta de Holbraad, voltemos a outra situação, em que a noçáo de verdade tem um lugar central, a saber, a maneira pela qual as falas dos meninos muitas vezes não vão ao encontro de suas açóes ou das informaçóes obtidas por outros meios. Alguns antropólogos adotam a posição do serviço social em geral que é a de tentar distinguir a verdade da fantasia, ou da mentira. Contudo, enquanto esse método pode servir para os problemas muito práticos (molares) de assistentes sociais e educadores - como fazer uma visita domiciliar se o menino, um dia, fala um endereço e, no próximo dia, outro? -, o trabalho do antropólogo se coloca a partir de outro problema, a saber, qual é o lugar da mentira e da fantasia nas vidas dessas crianças, adolescentes e educadores?

A fim de esclarecer tal proposta, uma breve elaboração do campo em si é necessária. $\mathrm{O}$ projeto de abordagem de rua que faz o meu campo atende um grupo de meninos e meninas que, habitualmente, dorme em um local próximo ao centro da cidade do Rio de Janeiro. Atualmente, o projeto funciona com encontros diários, de segunda-feira à sexta-feira, das $10 \mathrm{~h} 00$ às $12 \mathrm{~h} 30$, e, nas terças-feiras, das 10 h00 às 16h00. Nos dias de sol esse encontro acontece em uma praça pública onde existem três quadras de futebol, árvores com bancos e mesas na sombra para jogar damas, um parquinho para crianças, uma casinha para o guarda municipal (com banheiro e chuveiro) e um pequeno coreto (que normalmente serve como dormitório/banheiro para maiores de rua, mas que está sendo utilizado atualmente pelo grupo nos dias de chuva) sob o qual os garis da companhia municipal de limpeza guardam suas coisas.

Grande parte do trabalho é realizada na praça. As principais atividades desenvolvidas são o café da manhã, a higiene, o futebol, o desenho e a confecção de bijuteria - o futebol 
atrai a maioria dos meninos. Eles demoram entre vinte e trinta minutos para andar do local onde dormem até a praça e fazem esta viagem todos os dias, cedo, em baixo do sol forte, muitas vezes descalços. As crianças, adolescentes e maiores que são atendidos pelos educadores, formam um grupo muito heterogêneo, em termos de idade, sexo, origem e hábitos.

A idade do grupo varia entre 7 e 25 anos (crianças, adolescentes e adultos), mas também existem bebês e crianças mais jovens, que dormem na rua com suas mães. A maioria dessas últimas está na faixa de 14 a 17 anos de idade. É difícil dizer exatamente, mas o grupo consiste em, aproximadamente, quatro meninos para cada menina. A maioria vem do Estado do Rio de Janeiro, muitos da Baixada Fluminense, mas também há meninos e meninas de diversos outros Estados. O grupo tem um núcleo pequeno que vive na rua constantemente. Mas uma grande parte dos meninos e quase todas as meninas passam boa parte do seu tempo na rua e voltam para a casa da família, ou de algum amigo, durante o fim de semana ou quando ficam doentes. Uma vez por semana, a prefeitura também faz um "recolhimento" das crianças e adolescentes de rua. A maioria já passou por abrigos e os meninos utilizam esses espaços, de vez em quando, para saírem da rua por algum tempo, por diversos motivos. Porém, essa ação voluntária raramente torna-se uma mudança absoluta; os meninos e meninas fogem dos abrigos com a mesma facilidade com que entram.

Comecei a acompanhar o encontro entre educadores e meninos na segunda semana de março de 2005. Marquei um encontro na praça com a assistente social que acompanha os educadores. No primeiro dia cheguei cedo demais. As crianças começaram a chegar antes dos educadores. Vi-os chegando, à distância e, para mim, pareceu claro que se tratava do grupo que eu estava esperando. Ofereço ao leitor uma imagem da chegada desses meninos.
Eu estava sentada em um banco, tentando ficar à sombra porque, às dez horas da manhã, o sol começava a queimar e esquentar a minha cabeça. A praça estava mais ou menos deserta e parecia um oásis no meio das ruas. Do raro comércio e dos prédios abandonados que rodeiam a praça - uma ilha com árvores e flores no meio de um mar de concreto quente -, provinham as poucas pessoas que passavam ou sentavamse nos bancos, conversando, lendo o jornal ou dormindo. Um guarda municipal sentava perto do portão principal e garis tiravam folhas do gramado. Quando vi os primeiros meninos chegando, ainda à distância, no primeiro momento, na forte luz do dia, eles pareciam sombras magras e escuras atravessando as ruas, sombras que vinham de todas as direçóes para repousarem nos bancos da praça e se recuperarem: um devir-sombra ${ }^{20}$, um devir-molecular, que se reproduz sem cansaço, sem direção; um bando que mina as "grandes forças molares: família, profissão e conjugalidade" (Deleuze \& Guattari 1980: 285). Quase todos mantinham a mão

20. O “devir" está relacionado à economia do desejo: “Os fluxos de desejo procedem por afetos e devires, independentemente do fato de que possam ser calcados sobre pessoas, sobre imagens, sobre identificações. Assim, um indivíduo, etiquetado antropologicamente como masculino, pode ser atravessado por devires múltiplos e, aparentemente, contraditórios: devir feminino que coexiste com um devir criança, um devir animal, um devir invisível, etc. Uma língua dominante pode ser localmente capturada num devir minoritário" (Guattari \& Rolnik 1986: 318) Segundo Deleuze e Guattari, o devir é necessariamente um devir minoritário e molecular: "uma irresistível desterritorialização, que anula de saída as tentativas de reterritorialização edipiana, conjugal ou profissional” (1980: 285 - traduçấo da autora). O devir-sombra dos meninos se refere a seus movimentos entre os territórios marcados por eles dentro da cidade, quando se esforçam para não serem detectados e preferem andar sozinhos ou em grupos pequenos. Este devir se opóe ao devir-menino e ao devir-bando que os fazem aparecer e dominar um determinado território ou momento. 
na boca e logo pude reconhecer o thinner, pelo cheiro, que impregna até a pele dos meninos e queima seus pulmóes e suas máos. $\mathrm{O}$ cheiro começou a despertar-me outras sensaçóes, mais concretas, como se o cheiro do thinner atravessasse o calor do dia e me acordasse. Comecei a perceber mais os detalhes da "ilha" que era a praça - o fedor de fezes, a boca de fumo, a pança do guarda - e, com isso, também via, pela primeira vez, os corpos, rostos, olhos embaçados e sorrisos perdidos dos meninos.

Cada encontro tem uma estrutura. Quando os educadores consideram que reuniram um bom número de meninos - decisão que também depende daqueles que chegaram, e, ainda, de os meninos acharem que outros viráo - eles começam uma oração. Normalmente um educador puxa a oração começando com um curto discurso sobre o projeto, sobre algum acontecimento ou com uma história tirada da Bíblia. De vez em quando, os meninos também pedem para falar ou contribuem com o discurso do educador com exemplos pessoais do tema que está sendo tratado. Após esse discurso, a oração consiste em um "Pai Nosso" e uma "Ave Maria": um ritornelo ${ }^{21}$, com uma força fenomenal para pacificar os meninos. Após a oração,

21. Deleuze e Guattari denominam quatro tipos de ritornelo: "(1) ritornelos territoriais que buscam, marcam e agenciam um território; (2) ritornelos de função territorializada que assumem uma função especial no agenciamento (...o ritornelo dos Amantes que territorializa a sexualidade do amado...); (3) os mesmos, quando estes marcam novos agenciamentos, passam a novos agenciamentos por meio de desterritorialização-reterritorialização; (4) ritornelos que colecionam ou juntam forças, no centro do território ou para sair do mesmo (estes são refróes de confrontação ou de partida que às vezes trazem um movimento de desterritorialização absoluta...)" (1980: 402-3; tradução da autora). Aqui a oração aparece como o primeiro desses ritornelos, como um ritmo de agenciamento territorializante: como um centro pacificante e extremamente frágil no meio do caos no início de cada encontro. os educadores servem o café da manhá: suco ou leite com achocolatado e biscoito ou pão com manteiga. Normalmente, todos repetem o lanche. A fome de alguns meninos é interminável. Eles comem rápido e brigam por quererem comer mais, mesmo quando náo tem mais comida. No entanto, eles também dizem que não ficam sem comida porque várias "instituiçóes" os ajudam na rua. Eles dizem que recebem café da manhá, almoço de uma igreja, lanche e jantar de diversas pessoas; o que é confirmado pelos educadores. Porém, estes últimos também falam que eles deixam de comer mesmo quando têm com o que se alimentar, porque o thinner suprime o apetite. Mas, quando eles param de cheirar, dizem que a fome é desesperadora. Também há aqueles meninos que gostam de dar demonstraçôes do seu autocontrole para os outros meninos e para os educadores, e, por isso, chegam falando alto: “Tia, eu só quero um pão e um copo de Nescau”.

Terminando o café da manhá, os meninos correm direto para a quadra de futebol e se dispóem no jogo em times de cinco pessoas. Quando são poucos, os educadores também jogam; quando são muitos, a cada partida o time que perdeu sai e os que ficaram de fora formam um novo time. São poucos os meninos que não querem jogar, mas sempre há um ou dois. Já as meninas raramente jogam bola. Os que ficam de fora do futebol jogam vôlei, damas, dominó, bola de gude, fazem bijuteria, desenham e conversam com os educadores e a assistente social. Estes últimos tentam reconstruir as histórias de vida dos meninos - seus nomes reais (muitos usam apelidos ou nomes falsos), suas idades, suas naturalidades - e, a partir dessas informaçóes, procuram oferecer algum tipo de ajuda às crianças ou adolescentes, tais como: documentos, visitas domiciliares, acompanhamento médico etc.

Enquanto o maior objetivo do projeto é o "resgate individual" dos meninos e meninas, 
ou seja, tirá-los da rua, os educadores e a assistente social sabem que esse é um trabalho muito difícil e, portanto, também lhes oferecem o que é de mais valia: um lugar onde os meninos podem encontrar carinho e amizade. Embora esse último aspecto tenha também uma função molar de resgatar a auto-estima dos meninos com o objetivo maior de tirá-los da rua, molecularmente, no dia-a-dia, esses afetos se desenvolvem como base das relaçóes nos encontros. Os meninos expressam enfaticamente que o que os educadores têm a oferecer é felicidade, carinho e respeito. Como uma menina falou: "São poucas as pessoas que falam com a gente da forma que vocês falam, sem preconceito. São poucas as pessoas que não vêem a gente só como meninos de rua, e que não se aproveitam, mas tentam ajudar; que fazem coisas legais com a gente".

Os educadores e a assistente social procuram desenvolver novas atividades para os meninos e meninas. Uma dessas tentativas foi a de promover um dia de celebraçáo dos aniversariantes de cada mês. Essa comemoraçáo oferece uma situação interessante para retomar a questão da verdade e da mentira.

Em um dos encontros, a assistente social, Luísa, me pediu para ajudar a recolher as datas dos aniversários. Então, escolhemos um dia em que muitos meninos estavam reunidos e, durante o jogo de futebol, pedimos a todos que dissessem suas idades e datas de nascimento. Foi um exercício interessante. Alguns dos meninos respondiam à pergunta diretamente, mas muitos tinham dificuldade em lembrar as datas, suas idades e especialmente o ano em que nasceram. A lista abaixo apresenta as datas de nascimento e as idades dos 16 meninos que estavam presentes naquele dia:

Sérgio: 22/12/? - 22 ou 23 anos

Professor: 10/10/90 - 15 anos

João Grande: 21/08/82 - 23 anos
Pai-nosso: 08/06/81 - 24 anos

Silvio: 22/08/86 - 18 anos

Gato: 22/09/? - 15 ou 16 anos

Pirulito: 22/07/87 - 17 anos

Daniel: 18/03/81 - 24 anos

Tiago: 22/08/80 - 25 anos

Pedro Bala: 31/12/? - 13 ou 14 anos

Chinês: 03/10/79 - 26 anos

Charles: 25/12/89 - 16 anos

Capixaba: 10/04/84 - 25 anos

Paulista: 24/10/90 - 15 anos

Gordinho: 12/02/90 - 15 anos

Sem-Pernas: 02/07/? - entre 15 e 18 anos

Em primeiro lugar, percebe-se que, nesse dia, havia uma proporção muito grande de maiores, o que não é recorrente. Além disso, enquanto eu perguntava sobre os aniversários, o que mais me chamou a atenção foi o fato que muitos dos meninos nos diziam datas parecidas (as que estão em negrito). Esses meninos eram os que tinham mais dificuldade em se lembrar das datas dos seus aniversários. Eles formavam um grupo coeso, que demonstrava intimidade entre si, tendo em vista que dispunham de muita convivência, de muito "tempo de rua" juntos. Todos responderam à pergunta individualmente sem antes conversar com os outros, com a exceção do João-Grande ${ }^{22}$ que não pôde nos responder até que Silvio informou sua data, "só sei que meu aniversário é um dia antes do que o dele, tia”.

Sabemos que alguns dos meninos, como Sem-Pernas, não gostam de revelar suas idades porque querem permanecer como menores de idade. Especialmente para aqueles que aparentam fisicamente serem menores, apesar de não o serem, essa é uma posição importante frente à polícia, que significa não ir para a cadeia junto com os adultos. Em outro plano, ser menor

22. Os nomes utilizados aqui são uma mistura de nomes comuns que coloquei no lugar dos nomes reais e, no caso dos apelidos, usei aqueles criados por Jorge Amado em Capitães de Areia (1937). 
também significa: continuar a se relacionar com os outros menores, não ter que crescer, não ter que mudar ou "tomar uma atitude", continuar a ser um menino de rua.

A exemplo dessa necessidade de manter-se como um menor, relato a ocasião em que um senhor de mais ou menos 40 anos, morador de rua, veio me pedir uma quentinha no dia em que estávamos dando almoço aos meninos. Respondi a ele que primeiro iria servir comi$\mathrm{da}$ aos meninos e que depois eu lhe daria de comer; em seguida, ele me respondeu: "mas eu sou menino, tia". Muitos dos maiores no projeto continuam se considerando meninos e, assim, problematizam a linha oficial da ONG segundo a qual o projeto tem como prioridade oferecer serviços exclusivamente aos menores. Os educadores lidam com essa dificuldade diariamente, sabendo que a passagem à maioridade para os meninos - e, especialmente, para aqueles que estão na rua desde cedo - não é somente uma mudança de idade ou identidade, mas uma mudança de relaçóes, pois ser maior significa ter uma relaçáo diferente com a polícia, com as ONGs, com o tráfico e com os outros meninos de rua.

Podemos considerar a maneira por que alguns maiores se declaram mais novos como uma mentira ou fantasia que faz parte de sua eterna viração e sobrevivência. Porém, uma análise das datas dos aniversários em si e da semelhança entre elas, também fornece outro plano interessante para a representação desses dados. Como já coloquei, os meninos que deram as datas semelhantes são meninos que moram há muito tempo juntos na rua. Também, como foi explicitado, a passagem do tempo é um dado problemático para os meninos. Além do exemplo referido acima, os meninos têm muita dificuldade em equacionar suas experiências com o tempo e demonstram a mesma dificuldade em falar sobre o futuro. O que importa para eles é o tempo em que convivem juntos. É a relação entre eles na rua que os leva a saírem de casa e a passarem as maiores dificuldades, e até morrerem, para estarem juntos: "Porque eu voltei para a rua? Para visitar meus amigos, meus irmãos, tia”. Impressionante é a quantidade de meninos que estão em casa mas voltam para a rua, por alguns dias ou semanas, para visitarem seus amigos. Seria fácil dizer que é mais por causa das drogas. É certo que, em alguns casos, esse fator predomina, mas, em muitos outros, conheci meninos que não são usuários e que fazem essas "visitas" regularmente. Levando em consideração a importância dessas relações entre os meninos, podemos analisar a semelhança entre as datas de aniversário como uma expressão dessas relaçóes, desse tempo juntos, e, sobretudo, como uma visualização da união entre eles, o devir-bando dos meninos. Para voltar aos parâmetros teórico-metodológicos anteriores, ser menino de rua é uma identidade que os torna visíveis para o mundo exterior e eles sabem como utilizar essa identidade - para dar medo ou criar pena dependendo do contexto -, mas também é um agenciamento coletivo de enunciação, é a produção de uma subjetividade e uma definição inventiva - aqui tanto ser menino como de rua são sentidos desterritorializados e reterritorializados pelos meninos, em relação.

O tempo também faz aparecer outra dimensão, a do tato, e, em conexão com isto, a corporalidade. Para pensar essas questóes e, com isso, os movimentos molares e moleculares que as transversalizam, proponho que pensemos, provisoriamente, em dois planos de imanência (de vida): o plano estratégico e o plano tátil. O plano estratégico se refere às formas de socialidade que se baseiam na aplicação eficaz de recursos ou na exploração de condições favoráveis, visando o alcance de determinados objetivos - como no sentido de uma estratégia para sobreviver na rua, uma estratégia para sair da rua, uma estratégia para resgatar da rua ou até uma estratégia para o agenciamento - e que, portanto, 
utilizam a temporalidade como eixo para movimento. Por sua vez, o tato é uma experiência que ocorre em um certo vácuo temporal, quer dizer, não depende de recursos ou de condiçôes exteriores ao ator, mas da própria sensibilidade de cada ator ou grupo com relação ao seu ambiente físico ou relacional. Assim, o plano tátil indica formas de socialidade baseados na conexão criativa de diferentes experiências (táteis e estratégicas). Quanto ao campo em questão, o plano tátil se manifesta na maneira pela qual meninos e educadores se relacionam durante parte de seus encontros - fora de um contexto que depende do posicionamento social (condiçóes) de cada ator (educador, menino, menina) e que se direciona sempre a um determinado objetivo -, nas conseqüências dessa situação (as histórias contadas, as amizades formadas), e, também, no modo que esses atores passam, constantemente e com facilidade dessa forma tátil de se relacionar a uma situação "educativa” muito tradicional e extremamente estratégica. Essas passagens dependem da sensibilidade de cada ator, em conexão com outros atores e outras experiências. Ao mesmo tempo, a criação de novos territórios existenciais, em que relaçooes hierarquizadas podem existir ao lado de relaçóes cuja natureza nega tais hierarquizaçōes, depende da habilidade do ator em, estrategicamente, utilizar essas percepçóes para formar uma nova relação. Assim, o plano tátil e o plano estratégico podem ser entendidos através da relação interdependente e fractal entre a percepção e a criação. ${ }^{23}$

Geralmente falando, seria possível identificar os meninos como atuando em um plano mais tátil, no sentido em que a anti-tempora-

23. A corporalidade é um tipo de experiência particularmente apto para uma descrição da tatilidade, porém, vale enfatizar que não se deve pensar que a tatilidade depende da corporalide - a tatilidade não é puramente física e também se manifesta através de outros sentidos. lidade (e náo a ausência de) e a corporalidade influenciam fortemente o estilo em que eles se relacionam. Já os educadores estariam associados ao plano estratégico, na maneira em que, grosso modo, eles conceitualizam a razão do seu trabalho e os fatores que regem a concepção oficial de sucesso em um atendimento: o futuro - planejamento para, auto-estima para, responsabilidade para etc. Porém, o que também interessa é o modo como esses dois planos se cruzam molarmente, se agenciam e se articulam molecularmente no encontro entre meninos e meninas de rua e educadores de rua. Nesse sentido, as datas de aniversário dos meninos fornecem uma situação interessante dessa articulação, já que, no plano estratégico, eles fantasiam sobre suas idades e datas de aniversário por uma razão muito prática - ser menor quer dizer ser protegido -, mas, em outro sentido, o plano tátil também se expressa na maneira em que as datas também descrevem a relação íntima entre os meninos.

\section{Encontros Molares - Agenciamentos Moleculares}

$\mathrm{Na}$ análise de Guattari, o Capitalismo Mundial Integrado (CMI) é diferente de um capitalismo universal hegemônico ou totalizado. O CMI precisa ser variado e controlar diferentemente cada situação, além disso, ele depende da existência de linhas de fuga para a constante renovação de sua força. Guattari diz, nos Anos de Inverno, que o CMI é um sistema vampírico e, portanto, em conexáo com o platô do devir, ele é um sistema contagioso, um sistema molecular.

O vampiro não se afilia, ele contagia. A diferença é que o contágio, a epidemia, póe em jogo termos completamente heterogêneos: por exemplo, uma homem, um animal e uma bactéria, um vírus, uma molécula, um micro-organismo 
(Deleuze \& Guattari 1980: 295; tradução da autora).

Esse funcionamento vampírico, esse contágio, destaca um outro elemento central do CMI: a produção da subjetividade. O CMI, bem como sua habilidade reprodutiva, depende de um investimento profundo na construção da subjetividade e da flexibilidade, que, por sua vez, permite linhas de fuga, que permitem a vitalidade dos movimentos sociais...

As ONGs representam uma territorialização molar desta vitalidade, o que não quer dizer que os movimentos sociais também não façam esse movimento molar, ou que as ONGs não contenham elementos moleculares. Como já foi exposto, esses processos são interdependentes. Porém, acredito que, atualmente, as ONGs e a proliferação destas indica uma captura brutal e muito efetiva para a produção da subjetividade capitalística ${ }^{24}$. Segundo Hardt $\&$ Negri (2001), em uma reflexão sobre essa produção social, uma intervenção do Império se baseia numa intervenção moral:

O que chamamos de intervenção moral é praticado hoje por uma variedade de entidades, incluindo os meios de comunicação e organizaçôes religiosas, mas as mais importantes talvez sejam as chamadas organizaçóes náo-governamentais (ONGs), as quais, justamente por não serem administradas diretamente por governos, entende-se que agem a partir de imperativos éticos ou morais (2001: 54).

O "risco social" enfrentado pelos jovens em questão é o risco de exclusão de um sistema social - o CMI - e é fundamental entender o funcionamento dessa perspectiva: o significado é muito amplo e depende muito do contexto

24. Guattari utiliza o conceito 'capitalístico' para enfatizar a maneira em que o CMI depende da construçáo de subjetividades. em questão. A noção de "exclusão social" é um dispositivo rostificador que funciona para a identificação de um "problema" e sua "solução". Como foi colocado por Hardt e Negri, essas organizaçóes "lutam para a identificação de necessidades (...). Por meio de sua linguagem e de sua ação, eles primeiro definem o inimigo como privação e depois reconhecem o inimigo como pecado" (Ibidem: 55). A maior privação é a exclusão, porque só os incluídos, nessa perspectiva, podem ter acesso a tudo aquilo que o CMI oferece de "bom": casa, carro, família, emprego. Nesse sentido, a população de rua e, especialmente, as crianças são os mais excluídos, os mais "marginais", e vemos então que caímos em uma das divisóes binárias mais clássicas, o bem e o mal, porque, no final, se inclusão é tudo de bom, exclusão só pode ser tudo de ruim. A legitimação moral do CMI - como a única opção possível - é concreta e profunda.

O funcionamento do CMI é sutil porque ele funciona na produçáo da subjetividade, contudo, seria pura teorizaçáo dizer que dentro do funcionamento de ONGs e outras organizaçôes, as pessoas, por definição, atuam para cumprir todas as necessidades do sistema capitalístico. $\mathrm{Na}$ realidade, esse sistema tem suas brechas, especialmente em um encontro tão brutal entre molar e molecular, que se coloca no encontro entre o sistema capitalístico - as ONGs - e os meninos de rua. Muitas linhas de fuga são criadas e, por mais que estas tenham a tendência de se reterritorializarem duramente, existem momentos em que as linhas de fuga carregam o potencial de escapar ao muro branco e ao buraco negro. Portanto, as ONGs também carregam um potencial heterogênico. Esse potencial se revela na maneira em que os atores se conectam, tanto meninos quanto educadores, e tanto em suas relaçôes interpessoais quanto com relação à situação social em que eles se encontram. 
Cada um dos meninos e meninas de rua e dos educadores tem suas histórias e suas experiências que repercutem no projeto de diferentes maneiras, segundo as relaçóes que os meninos estabelecem entre eles, com os educadores e comigo, claro. Contudo, certos personagens parecem se conectar mais com minhas atuais reflexóes, por motivos que logo se tornaram óbvios. Nesse momento, eu lhes apresento duas dessas pessoas: Pedro Bala (13 anos), menino de rua; e Maria, educadora e ex-menina de rua. A partir de uma breve descrição desses atores e da maneira pela qual eles se relacionam e se conectam com os diversos elementos do campo, pretendo esboçar uma visão mais clara das idéias colocadas neste trabalho.

Os três atuais educadores sociais (título oficial) do projeto em que realizei a minha pesquisa de campo são ex-beneficiários da $\mathrm{ONG}$ que financia o projeto e todos ainda fazem parte de outro projeto que visa fornecer "cidadania" através de seus trabalhos. Daniel nunca foi "de-rua", mas vem de uma comunidade-favela da Zona Sul do Rio de Janeiro. Samuel já morou na rua, mas não se considera como "exde-rua", mas como "ex-infrator" - por razóes que não tenho espaço de elaborar no presente trabalho. Ele foi "acolhido" pela ONG e atualmente também coordena uma escolinha de futebol nos fins de semana, financiado pela mesma ONG, em um bairro no subúrbio do Rio de Janeiro. Maria morou durante cerca de dez anos na rua, no centro do Rio de Janeiro, e se considera "ex-de-rua". Atualmente, além de trabalhar no projeto de abordagem de rua, ela também cumpre diversos papéis em outros projetos da ONG. Dos três educadores, o único que chegou ao ensino superior foi Daniel, que atualmente cursa Serviço Social em uma universidade particular, financiado pela mesma ONG. A formação deles como educadores sociais se baseia em cursos informais de curta duração.
Maria foi para a rua com sua mãe, quatro irmãs e dois irmãos, aos seis anos de idade, após a separação dos pais, situação que deixou a mãe e as crianças desabrigadas. Sua mãe ainda conseguiu alugar um barraco em um bairro longe do centro do Rio de Janeiro, mas, nas idas e vindas da casa para a rua (onde ela vendia doces), eles acabaram perdendo o barraco e seus pertences. Logo que começaram a morar na rua, o irmão mais novo de Maria foi levado por um casal - ela diz que, na época, não existiam termos para se dizer que ele havia sido seqüestrado - e foi criado por outra família. Ela e suas irmãs só reencontraram este irmão muito tempo depois, quando ele já era adulto. $\mathrm{O}$ outro irmão mais velho morreu "por causa do sofrimento que ele passou na rua”. Maria passou a ser responsável pelas suas quatro irmãs, já que a saúde de sua mãe também começou a ser prejudicada por viver na rua. Ela diz que foi "resgatada" da rua, por outro projeto que trabalhava com meninos e meninas de rua, na época, no centro do Rio de Janeiro. Também era um projeto de abordagem através do qual, após muito tempo e muitas "conquistas", ela conseguiu sair da rua. Começou a estudar e, para que tivesse uma ocupação e, assim, ficasse fora da rua, ganhou uma "função" dentro do projeto. Mas suas irmãs e sua mãe continuavam morando na rua. Foi só depois que Maria falou que náo conseguia sair da rua sem sua família que o projeto levantou dinheiro e comprou um barraco numa comunidade-favela na periferia do Rio de Janeiro. Nessa ocasião ela tinha dezesseis anos de idade e, logo que se mudaram para lá, sua mãe faleceu. Maria ainda mora no mesmo bairro.

Quando Maria saiu da rua, uma de suas primeiras "funçôes" dentro do projeto, que a atendia na época, foi como auxiliar de educação em uma casa. Ela organizava atividades para meninos e meninas de rua durante o dia. Maria diz que um educador e coordenador do projeto, 
Fernando - que também foi um dos fundadores da ONG para a qual ela trabalha atualmente - viu que ela tinha uma vocaçáo para ajudar os meninos e meninas e sugeriu que ela começasse a aprender o cargo de educadora. Ela diz que uma das razóes pelas quais ela se interessou por esse cargo foi por ver educadores fazerem e falarem coisas que ela náo achava certo quando ela era menina de rua:

A pior coisa que se pode falar para um desses meninos é que não tem mais jeito. Quando eu era menina de rua eu era muito danada e tomava muitas drogas. Eu ouvi educadores falarem que náo tinha mais jeito para mim e sempre pensava que se eu fosse educadora não faria isso. Sempre tem jeito, ainda mais quando se fala de crianças.

Maria afirma que para quem já passou por isso é mais fácil entender o que os meninos pensam, como e porque eles reagem:

A rua foi uma faculdade para mim. Para quem já viveu isso, é mais fácil entender a maneira em que esse meninos e meninas são violentados de todas as formas, não só de forma física, mas mesmo no olhar, na falta de respeito, no fato de você não ter onde chamar de casa ou paradeiro, porque quando você acorda de manhã as pessoas te expulsam e jogam um balde de água em você.

Maria fala que as pessoas que não conhecem os meninos náo sabem de suas vidas e nem querem saber; dão dinheiro, mas querem distância:

Comida eles arrumam em qualquer lugar, mas carinho e amor, tocar e ser tocado, isso é mais difícil e é isso que a gente dá a eles. E aqui você tem que saber com quem você trabalha, você é agredido, é um trabalho difícil. Eu sei porque eu passei por isso. Tudo tem sua teoria e sua prática, minha experiência de rua foi a prática, aqui é a teoria para mim.

Maria sabe mais do que ninguém das dificuldades da vida na rua, mas também ressalta que certas atitudes são difíceis de encontrar fora da rua:

Você pode estar dormindo debaixo de um viaduto com outra pessoa que você não conhece e que está na mesma situação que você, mas, mesmo assim, o pouco que ela tiver ela divide com você. Enquanto tem muitas pessoas que têm condiçóes muito melhores, que não te dão nada. Esse é o bom da rua, são as pessoas e a convivência com elas.

É evidente que a vida de Maria revela muitas "conquistas": o fato de ter tirado sua família da rua, de ter conseguido sua casa, de seguir com seus estudos e de "dar condiçôes" a seu filho. Maria fala da dificuldade que teve em largar a rua e mudar de vida e de atitude. Porém, também podemos dizer que, por mais que ela tenha saído da rua, as condiçóes em que ela saiu também são muito especiais. Maria não é mais de-rua, mas seu relacionamento com os meninos e as meninas de-rua continua. Essa possibilidade de manutenção de vínculo, nesses termos, não é comum. $\mathrm{O}$ encontro molar de Maria com a ONG, que lhe ofereceu sua saída de uma vida violenta e difícil, tanto fisicamente quanto conceitualmente, proporcionou condiçóes para que ela continuasse a se relacionar com os meninos e meninas que ficaram na rua - não os da sua geraçáo ${ }^{25}$, mas a dos atendidos pelos projetos de abordagem - e, também, com os meninos e meninas com os quais ela

25. "Dos que ficaram na rua, muitos já morreram, muitas meninas viraram prostitutas, outros conseguiram um barraquinho, casaram e estão trabalhando, mas além dos educadores vejo eles pouco e somente por acaso". 
conviveu na rua e que tiveram a mesma oportunidade que ela (Maria parece conhecer todos os educadores de rua da cidade) e organizaçóes e coordenadores (antigos educadores) que também a atenderam quando era menina de rua.

Essa situação foi estimulada por Maria da mesma maneira intensa e tátil com que ela se relaciona com os outros e resultou em uma rede de relaçóes impressionante, pois - além das relaçóes do passado, no antigo projeto que a atendeu, e com todas as pessoas com quem ela conviveu naquela época - Maria também se relaciona ativamente com os meninos e meninas de rua que ela atende no projeto de abordagem atual.

Ela baseia muitas de suas avaliaçóes sobre os meninos e outras pessoas no modo como eles olham e se movem: "eu sei quando um menino quer falar mas não sabe como, pelo seu olhar, pela sua forma de se mexer". Esse modo ilimitado e, por isso, molecular de se relacionar, tende a entrar em conflito com a visão mais "profissional" da assistente social que critica o fato de Maria não conseguir romper relaçóes com meninos e meninas que já foram "resgatados" pela organização, mas que continuam a pedir apoio. Os meninos tendem a ligar para a Maria antes de ligar para a assistente social ou para os coordenadores. Um exemplo foi o caso de Regina, uma ex-menina-de-rua que foi atendida pela ONG no passado e que recebeu um barraco para ela e seus cinco filhos nesse atendimento. Recentemente ela engravidou novamente, mas a criança nasceu prematura de quatro meses e foi incubada. A primeira pessoa para quem ela ligou, a cobrar, do hospital, numa sexta-feira, foi para Maria, pedindo companhia e ajuda, pois, ela náo tinha dinheiro nem roupas. A ligação caiu sem que Regina falasse o nome do hospital em que ela estava, Maria passou o seu fim de semana e feriado procurando a menina nos hospitais públicos da Baixada Fluminense e do Rio de Janeiro para levar roupas para ela e para a criança. Ao encontrá-la, além das roupas, ela também deixou um pouco de dinheiro e um cartáo telefônico. "Uma pessoa náo deixa de ser um atendido nosso só porque saiu da rua", ela me disse na ocasião. Certamente, essa atitude é estimulada até um determinado ponto, o que se vê na maneira pela qual ela foi atendida, mas Maria se ressente que as coisas tenham mudado e por isso se esforça para manter sua independência da ONG e de qualquer outra pessoa. Maria se orgulha por não ter que, fisicamente, depender de ninguém: "A única coisa que eu não sei fazer é mexer com computador, mas isso eu também vou aprender".

A forma como Maria pensa suas relaçóes, tanto com os meninos como com os outros educadores, a assistente social e os coordenadores, e a maneira como ela age nessas relaçóes - através do toque, do controle da distância física, de um olhar ou sorriso, da ausência de um limite de relação - é indicativo daquilo que nomeio de um plano tátil de relacionamento, um agenciamento molecular de fluxos heterogêneos. Porém, também é importante destacar o plano estratégico: no modo como ela afirma sua independência e auto-suficiência, no jeito assertivo com que ela se relaciona com os outros e nas suas falas a respeito de como ela teve que ser "resgatada" da rua - "eles me mostraram quem eu era com um espelho e, assim, levantaram minha auto-estima”. Movimentos molares e moleculares funcionam no processo de definição inventiva (que ao meu ver não se restringe somente a conceitos ou palavras, como também se desenvolve na forma pela qual os atores se relacionam) simultaneamente nas açóes e nas falas de Maria.

Os meninos e meninas de rua que conheci no projeto de abordagem apresentam esses mesmos movimentos: o plano tátil, muitas vezes, parece escamotear o plano estratégico; o molecular parece afogar o plano molar, mas em seus encontros altamente molares com os 
educadores de rua esses dois planos aparecem e, assim, eles fazem funcionar e aparecer a potência de redundância, de loucura, de morte e de criatividade, tudo ao mesmo tempo.

Pedro Bala tem mais ou menos treze ou quatorze anos de idade. Ele mora na rua desde os 5 ou 6 anos de idade. Sua mãe também morou na rua durante muito tempo. Atualmente ele tem pouco contato com sua máe, que mora em um pequeno barraco em um antigo galpão abandonado onde cerca de 30 famílias construíram suas pequenas casas de madeira e papeláo, ao lado de uma das novas e enormes construçóes laranjas do prefeito César Maia. Ele tem um irmáo mais velho, Anderson (de 25 anos), que também mora na rua há muito tempo e que participa dos encontros regularmente, mas, atualmente, ele está ficando mais tempo na casa de sua mãe. Os dois fazem parte de um núcleo estabelecido dentro do grupo maior de meninos e meninas que se reúnem com os educadores diariamente. Os outros meninos, no entanto, também costumam se diferenciar dos dois irmãos por serem mais escuros e por terem uma família visivelmente muito pobre. Todos conhecem a máe dos dois irmãos, que, segundo os meninos, é alcoólatra e costuma procurá-los onde os meninos costumam dormir. A maioria dos meninos vem de famílias de baixa renda da Baixada Fluminense e não do centro do Rio de Janeiro. A visibilidade da situação familiar de Pedro e Anderson parece diferenciá-los. Pedro Bala raramente falta aos encontros com os educadores que têm um carinho muito especial por ele, mas ao mesmo tempo todos (educadores e meninos) identificam Pedro como um menino que perturba muito - ele está sempre brincando e provocando o grupo como um todo. Nessas situaçóes, os meninos tendem a chamar a atenção de Anderson para controlar seu irmão. Em outras ocasióes mais sérias, os meninos tentam bater em Pedro, mas ele é muito rápido e ao mesmo tempo Maria diz que os outros meninos "têm pena do Pedro Bala", por causa de sua situaçáo extrema - Pedro e Anderson são dois meninos que perturbam muito os educadores e a função molar do projeto porque eles não acreditam que os meninos tenham uma saída. De fato, apesar da gozaçáo dos meninos, Pedro e Anderson despertam muita simpatia dentro do grupo e até as meninas de rua tentam sugerir a Pedro que ele deve conversar com sua mãe, mas ele se recusa.

Nos encontros, Pedro Bala se faz sempre notar em função da maneira como se relaciona com todos, tanto educadores, quanto meninos. Ele fala pouco, a não ser quando está brincando com alguém no futebol. Mas ele abraça, morde, beija e belisca o tempo inteiro. A relação com o Pedro é intensa e acontece quase completamente a partir do corpo. O que ele mais gosta de fazer nos encontros, além de jogar futebol (ele é um artilheiro e goleiro talentoso), é ficar pendurado no pescoço de um educador ou menino, mordendo, beliscando e beijando. Ele nunca freqüentou a escola. Assim como Anderson, ele aprendeu na rua a ler um pouco e a contar. Diferentemente de seu irmáo e de todos os outros meninos do grupo, Pedro nunca usou drogas e nunca volta para casa. A pista é o reino de Pedro Bala, ele passeia pelas ruas, sozinho ou com seus amigos. Ele degusta todos os prazeres e sofrimentos que as ruas do Rio de Janeiro têm a oferecer. Ele também é um observador astuto e suas observaçóes se molarizam em seus lindos desenhos e sob a forma de agressão verbal e física. É difícil imaginá-lo fora da rua e a rua sem Pedro Bala. Os educadores identificam essa situação e a maior frustração é não ter o que oferecer a um menino como ele, além de muito carinho.

Pedro, sua maneira de se relacionar e viver, pode ser muito bem considerado como o exemplo por excelência do plano tátil. Sua corporalidade e espontaneidade indicam isso e, com certeza, seria difícil encontrar tantos elementos desse território como encontramos 
em suas ações. Porém, sua fala e sua identificação absoluta com a rua, que também se evidência na sua total lealdade aos educadores e aos encontros com eles, demonstra a maneira com que o plano estratégico funciona em seus relacionamentos e em suas experiências de rua. Uma indicação desse plano molar é a maneira como, apesar de todas as suas brincadeiras, Pedro é um dos meninos que mais leva a sério o momento de oração e o respeito pelos educadores - tudo que ele parece querer é se agenciar.

Pedro Bala é independente, foge das tristezas que encontra na casa de sua mãe. Anderson nunca consegue convencer seu irmão a voltar para o pequeno barraco que sua máe oferece como alternativa. Apesar de suas tentativas de se agenciar com o exterior (da rua), Pedro faz sua vida inteiramente na rua, porque a vida que ele conhece e que ele criou está na rua. Sua afetividade com outros meninos e meninas, com os bebês das meninas de rua e com os educadores indica seu território existencial. A molecularidade de suas relaçóes se reterritorializa na rua e, por enquanto, somente na rua.

A situação dos meninos e meninas de rua que conheci nesses últimos dez meses é difícil e violenta. Ela não representa de forma alguma uma realidade utópica. Ao mesmo tempo, não deixa de ser palco para uma criatividade que revela formas de relacionamento com os quais talvez tenhamos muito a aprender. Nessa linha, o trabalho que continuo a desenvolver tem como uma de suas motivaçóes principais um desejo de afetar os leitores, sejam eles antropólogos, outros acadêmicos ou pessoas que se interessam por esses atores, por razóes profissionais ou não, da mesma maneira como fui afetada pelas amizades que esses meninos, meninas e educadores me ofereceram durante meu tempo de pesquisa de campo.

\section{Cartographic meetings: reflections on meeting between boys and street educators}

abstract This work has as its objective the connection between a fieldwork about the meetings between street children and educators and theoretic-methodological perspectives that aim to relocate ethnographic representation. For this end, a contrast is offered between recent anthropological analyses about this theme, in which an interpretation is elaborated through the use of terms such as family and society and an analysis that begins with the social relations that run through these terms and beyond. As such, an attempt is made to elicit the multiple social planes and relations that cross this theme. This article tries to elaborate an alternative for the analysis of phenomena that are normally defined by their "lack of..." and thus outlines reflections about the very idea of one ethnographic "reality".

keywords Street children. NGOs. Urban anthropology. Ethnography. Truth.

\section{Referências bibliográficas}

AMADO, Jorge. [1937]. Capitães de Areia. Rio de Janeiro: Record, 1991.

DELEUZE, Gilles \& GUATTARI, Félix. 1980. Mille Plateaux: Capitalisme et Schizophréne. Paris: Minuit.

DONZELOT, Jacques. [1977]. A Polícia das Famílias. Rio de Janeiro: Ediçôes Graal, 1980.

GOLDMAN, Marcio. 1994. Razão e Diferença: Afetividade e relativismo no pensamento de Lévy-Brubl. Rio de Janeiro: Grypho.

GREGORI, Maria Filomena. 2000. Viração: Experiências de meninos nas ruas. São Paulo: Companhia das Letras.

GUATTARI, Félix. [1977]. Revolução Molecular. Pulsaçôes Politicas do Desejo. São Paulo: Brasiliense, 1987. 1986. Les Années d'Hiver. Paris: Barrault. [1992]. Caosmose: Um novo paradigma estético. São Paulo: Editora 34, 2000.

GUATTARI, Félix \& ROLNIK, Suely. Micropolitica. Cartografias do Desejo. Petrópolis: Vozes, 1986. 
HARDT, Michael \& NEGRI, Toni. 2001. Império. Rio de Janeiro: Record.

HECHT, Tobias. 1998. At Home in the Street. Cambridge: Cambridge University Press.

HOLBRAAD, Martin. 'Defining Anthropological Truth'. Paper for Truth Conference, Cambridge, September 2004. Disponível em: http://abaete.wikicities.com/ wiki/Defining_anthropological_truth_\%28Martin_ Holbraad\%29

NIETZSCHE, Friedrich. [1887]. Genealogia da Moral: Uma Polêmica. São Paulo: Companhia das Letras, 1998.

RIZZINI, Irene et alli. 1992. Childhood and Urban Poverty in Brazil: Street and Working Children and their Families. Florence: UNICEF ICDC.

STRATHERN, Marilyn. 1987. "The Limits of Auto-Anthropology". In: Anthony Jackson (eds.), Anthropology at Home. Cambridge: University of Cambridge Press. 1988. The Gender of the Gift:
Problems with Women and Problems with Society in Melanesia. Berkeley: University of California Press.

WAGNER, Roy. 1974. "Are there social groups in the New Guinea Highlands?" In: M. J. Leaf (ed.), Frontiers of Anthropology. New York: D. Van Nostrand. . [1975]. The Invention of Culture. Chicago: The University of Chicago Press, 1981.

\section{Agradecimentos}

A Marcio Goldman, pela orientação sempre inspiradora; a Luciana França, Virna Plastino e Camila Medeiros Pinheiros, pelas revisóes; aos educadores e aos meninos e meninas pelas liçóes e pelo carinho. Este trabalho é dedicado aos meninos, e amizades, que perdemos e que recebemos nesse último ano.

\section{autor Julia Frajtag Sauma \\ Mestranda em Antropologia Social / MN-UFRJ}

Recebido em 15/02/2006

Aceito para publicação em 25/07/2006 